\title{
PENGARUH BRAND IMAGE, HARGA, DAN PROMOSI TERHADAP KEPUTUSAN PEMBELIAN PADA WARUNG MIE REBUS PAK JAMBANG AEK NABARA
}

\author{
Raja Saul Marto Hendry, Daslan Simanjuntak \\ Fakultas Ekonomi dan Bisnis Universitas Labuhanbatu \\ Email : rajasaul365@gmail.com
}

\begin{abstract}
ABSTRAK
Penelitian ini bertujuan untuk untuk mengetahui pengaruh brand image, harga, dan promosi terhadap keputusan pembelian pada Warung Mie Rebus Pak Jambang Aek Nabara, baik secara parsial maupun simultan. Populasi dalam penelitian ini adalah para pelanggan yang berkunjung ke Warung Mie Rebus Pak Jambang selama waktu penelitian yang jumlahnya tidak dapat ditentukan secara pasti. Penentuan jumlah sampel menggunakan rumus Wibiso dengan jumlah 96 orang dan teknik pengambilan sampel menggunakan metode accidental sampling. Metode analisis yang dipergunakan adalah metode analisis deskriptif, metode analisis statistik yang terdiri dari uji asumsi klasik, analisis regresi linier berganda, dan uji hipotesis.

Hasil pengujian hipotesis secara parsial (uji t) menunjukkan bahwa brand image $\left(X_{1}\right)$ dan harga $\left(X_{2}\right)$ berpengaruh positif dan signifikan terhadap keputusan pembelian pada Warung Mie Rebus Pak Jambang Aek Nabara, dimana untuk brand image $\left(X_{1}\right)$ nilai thitung $(8,607)>$ $t_{\text {tabel }}(1,66159)$ dengan taraf signifikansi $0,000<0,05$ dan variabel harga $\left(X_{2}\right)$ nilai thitung $(4,731)>t_{\text {tabel }}(1,66159)$ dengan taraf signifikansi $0,000<0,05$. Sedangkan promosi $\left(X_{3}\right)$ berpengaruh positif tetapi signifikan terhadap keputusan pembelian pada Warung Mie Rebus Pak Jambang Aek Nabara, dimana thitung $(1,134)<t_{\text {tabel }}(1,66159)$ dengan taraf signifikansi $0,260>0,05$. Hasil uji hipotesis secara simultan (uji $F$ ) menunjukkan bahwa brand image $\left(X_{1}\right)$, harga $\left(X_{2}\right)$, dan promosi $\left(X_{3}\right)$ berpengaruh positif dan signifikan terhadap keputusan pembelian pada Warung Mie Rebus Pak Jambang Aek Nabara, dimana nilai $F_{\text {hitung }}(60,117)>$ $F_{\text {tabel }}(2,70)$ dengan taraf signifikansi $0,000<0,05$. Berdasarkan hasil uji determinasi diketahui bahwa keputusan pembelian dapat dijelaskan oleh variabel brand image, harga, dan promosi sebesar $65,1 \%$. Sedangkan sisanya 34,9\% dapat dijelaskan oleh variabel lain yang tidak dibahas dalam penelitian ini.
\end{abstract}

Kata kunci : Brand image, Harga, Promosi, Keputusan pembelian.

\section{PENDAHULUAN}

Labuhanbatu merupakan daerah yang kaya dengan berbagai jenis makanan khas (kuliner). Salah satu diantaranya adalah makanan olahan mie rebus yang sudah tidak asing lagi di masyarakat. Mie Rebus Pak Jambang adalah salah bentuk usaha kecil dalam bisnis kuliner yang sudah dikenal oleh masyarakat Aek Nabara dan sekitarnya bahkan sudah dikenal di Labuhanbatu. Usaha ini dijalankan oleh keluarga Bapak Abdullah atau lebih dikenal dengan nama Pak Jambang, sehingga usahanya juga diberi nama Mie Rebus Pak Jambang. Usaha ini telah berjalan lebih dari 10 tahun dengan berbagai pasang surut keadaan yang dilalui, mulai dari hanya warung sederhana sampai menjadi usaha yang cukup besar saat sekarang ini.

Merek (brand) bukanlah sekedar nama, istilah (term), tanda (sign), simbol atau kombinasinya. Lebih dari itu merek adalah janji perusahaan secara konsisten memberikan features, benefits, dan services kepada para pelanggan, dan janji inilah yang membuat masyarakat luas mengenal merek tersebut lebih dari yang lain. Dari pernyataan tersebut 
membuktikan bahwa citra merek (brand image) dapat memberikan keyakinan bagi konsumen dalam melakukan pembelian suatu produk. Karena persepsi kualitas merupakan persepsi konsumen maka dapat diramalkan jika persepsi kualitas konsumen negatif, produk tidak akan disukai dan tidak akan bertahan lama di pasar. Sebaliknya, jika persepsi kualitas pelanggan positif, produk akan disukai, dengan beranggapan bahwa kualitas produk yang baik merupakan jaminan kepuasan dalam menggunakan produk tersebut untuk memenuhi kebutuhan hidupnya. Dengan persepsi kualitas yang baik akan menciptakan suatu image yang baik bagi suatu produk yang akan menimbulkan keputusan pembelian oleh konsumen. Dari pernyataan tersebut membuktikan bahwa brand image (citra merek) merupakan persepsi yang terbentuk dimasyarakat (konsumen atau pelanggan) tentang baik buruknya produk atau perusahaan.

Selain itu, harga juga merupakan salah satu faktor penting, karena dengan kondisi sekarang ini produk yang berkualitas mempunyai nilai lebih dibandingkan dengan produk pesaing. Harga adalah satu-satunya unsur bauran pemasaran yang menghasilkan pendapatan penjualan karena unsur yang lain adalah mengeluarkan biaya. Harga merupakan sejumlah uang yang dibutuhkan untuk mendapatkan sejumlah kombinasi dari barang beserta pelayananya.

Warung Mie Rebus Pak Jambang menyediakan menu utama mie rebus dan aneka makanan lainnya dengan kualitas rasa yang mempunyai nilai lebih dibandingkan dengan produk lainnya yang sejenis. Warung Mie Rabus Pak Jambang mungkin bukan yang pertama di daerahnya, tetapi sampai saat ini tetap diminati banyak pelanggan bahkan dari luar daerah dengan brand Mie Rebus Pak Jambang yang dikenal enak dan harga yang terjangkau oleh konsumen. Untuk 1 posri mie rebus dijual dengan harga Rp 11.000,-. Selain itu, untuk lebih memperkaya produknya, warung mie rebus pak jambang juga menyediakan aneka minumam dan makanan ringan serta menerima pesanan baik dalam jumlah besar maupun kecil.

Di lihat dari segi brand image (citra merek) dan harga sudah tidak di ragukan lagi, tetapi itu saja tidak cukup untuk meyakinkan konsumen, oleh karena itu untuk dapat mengenal produk yang diciptakan dengan segala keunggulanya tersebut pada konsumen maka perusahaan perlu menerapkan strategi promosi yang baik. Promosi adalah arus informasi satu arah yang dibuat untuk mengarahkan seseorang atau organisasi kepada tindakan yang menciptakan pertukaran atau transaksi dalam pemasaran. Dengan promosi menyebabkan orang yang sebelumnya tidak tertarik untuk membeli suatu produk atau jasa akan menjadi tertarik dan mencoba produk atau jasa sehingga konsumen melakukan pembelian. Warung Mie Rebus Pak Jambang juga melakukan promosi meskipun tidak terlalu banyak, misalnya dengan iklan radio dan spanduk. Akan tetapi dengan promosi yang tidak terlalu aktif ternyata pelanggan warung mie rebus Pak Jambang tetap banyak.

\section{TINJAUAN PUSTAKA}

Brand Image (citra merek) adalah sekumpulan asosiasi merek yang terbentuk dan melekat di benak konsumen. Konsumen yang terbiasa menggunakan merek tertentu cenderung memiliki konsistensi terhadap brand image. Citra merek ialah persepsi dan keyakinan yang dilakukan oleh konsumen, seperti tercermin dalam asosiasi yang terjadi dalam memori konsumen (Kotler, 2009:346).

Citra merek kadang-kadang dapat berubah, ketika dibutuhkan suatu perubahan citra merek maka model peran yang harus ditemukan. Sebagai bagian dari identifikasi merek, model peran tersebut seyogianya dapat mewakili elemen identitas inti sebuah merek (surachman, 2008:108).

Harga adalah jumlah uang yang harus dibayar pelanggan untuk memperoleh produk. Kotler (2008:62). Terdapat tiga indikator mencirikan harga, yaitu keterjangkauan harga, 
kesesuaian harga dengan kualitas produk, dan kesesuaian harga dengan manfaat (Stanton, 2007).

Promosi menurut Giltosudarmo dalam Sunyoto (2012:155) adalah merupakan kegiatan yang di tujukan untuk memengaruhi konsumen agar mereka dapat menjadi kenal akan produk yang ditawarkan oleh perusahaan kepada mereka dan kemudian mereka menjadi senang lalu membeli produk tersebut.

Keputusan pembelian merupakan suatu tindakan yang dilakukan konsumen dikarenakan adanya dorongan-dorongan atau motif-motif yang dirasakan sehingga menimbulkan minat atau dorongan untuk memenuhi kebutuhan.

Berdasarkan uraian-uraian diatas maka hubungan antara variabel-variabel bebas dan variabel terikat dalam penelitian ini digambarkan dalam kerangka konseptual sebagai berikut :

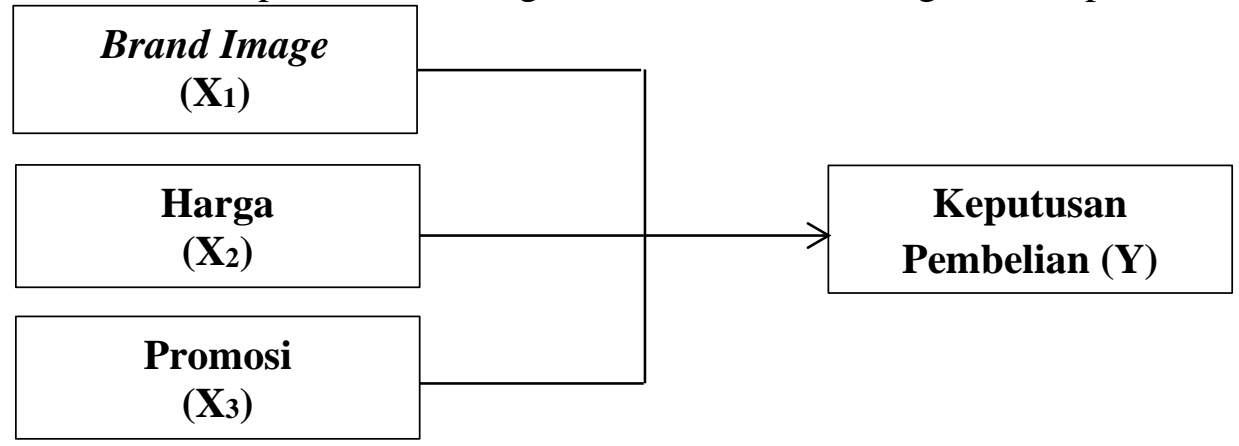

Gambar 1 Kerangka Konseptual

Hipotesis merupakan jawaban sementara terhadap rumusan masalah penelitian, dimana rumusan masalah telah dinyatakan dalam bentuk kalimat pertanyaan (Sugiyono, 2010:93).

Berdasarkan kerangka konseptual, maka hipotesis dalam penelitian ini adalah :

1. Brand image berpengaruh positif dan signifikan terhadap keputusan pembelian pada Warung Mie Rebus Pak Jambang Aek Nabara.

2. Harga berpengaruh positif dan signifikan terhadap keputusan pembelian pada Warung Mie Rebus Pak Jambang Aek Nabara.

3. Promosi berpengaruh positif dan signifikan terhadap keputusan pembelian pada Warung Mie Rebus Pak Jambang Aek Nabara.

4. Brand image, Harga, dan Promosi berpengaruh positif dan signifikan terhadap keputusan pembelian pada Warung Mie Rebus Pak Jambang Aek Nabara.

\section{METODE}

\section{A. Populasi dan Sampel}

Populasi adalah sekelompok elemen yang lengkap, yang biasanya berupa orang, objek atau kejadian dimana kita tertarik untuk mempelajari suatu objek penelitian (Kuncoro, 2009:115). Yang menjadi populasi dalam penelitian ini adalah pelanggan Warung Mie Rebus Pak Jambang yang jumlahnya tidak dapat ditentukan secara pasti.

Menurut Sugiyono (2010 : 118) sampel adalah bagian dari jumlah dan karakterisitik yang dimiliki oleh populasi tersebut. Dapat disimpulkan bahwa sampel merupakan bagian dari populasi yang mempunyai karakteristik dan sifat yang mewakili seluruh populasi yang ada.

Karena populasi dalam penelitian ini tidak diketahui jumlahnya, menurut Wibisono (dalam Riduwan dan Akdon, 2013 : 255) rumus dalam menghitung sampel pada populasi yang tidak diketahui adalah sebagai berikut : 
Keterangan :

$$
n=\left[\frac{Z_{\alpha / 2} \cdot \delta}{\varepsilon}\right]^{2}
$$

$$
\begin{aligned}
\mathrm{n} & =\text { jumlah sampel } \\
\mathrm{Z} \alpha & =\text { nilat tabel } \mathrm{Z}=0,05 \\
\delta & =\text { standar deviasi } \\
\varepsilon & =\text { margin error }
\end{aligned}
$$

Dengan demikian, jumlah sampel dalam penelitian ini adalah :

$$
n=\left[\frac{Z_{\alpha / 2} \cdot \delta}{\varepsilon}\right]^{2}=\left[\frac{(1,96)(0,25)}{0,05}\right]^{2}=96,04 \approx 96 \text { orang }
$$

\section{B. Metode Analisis Data}

\section{Analisis Deskriptif}

Metode analisis deskriptif merupakan cara merumuskan dan menafsirkan data yang ada sehingga memberikan gambaran yang jelas melalui pengumpulan, penyusunan, dan penganalisisan data sehingga dapat diketahui gambaran data yang sedang diteliti. Data diperoleh dari data primer berupa kuesioner yang telah diisi oleh sejumlah responden penelitian.

\section{Uji Asumsi Klasik}

Sebelum data dianalisis, maka model regresi berganda harus memenuhi syarat uji asumsi klasik.

\section{a. Uji Normalitas}

Data-data bertipe skala sebagai pada umumnya mengikuti asumsi distribusi normal. Namun, tidak mustahil suatu data tidak mengikuti asumsi normalitas. Untuk mengetahui kepastian sebaran data yang diperoleh harus dilakukan uji normalitas terhadap data yang bersangkutan. Dengan demikian, analisis statistika yang pertama harus digunakan dalam rangka analisis data adalah analisis statistik berupa uji normalitas. Menurut Ghozali (2009:147) uji normalitas bertujuan apakah dalam model regresi variabel dependen (terikat) dan variabel independen (bebas) mempunyai kontribusi atau tidak.

Salah satu cara termudah untuk melihat normalitas residual adalah dengan melihat grafik histogram yang membandingkan antara data observasi dengan distribusi yang mendeteksi distribusi normal. Namun demikian hanya dengan melihat histogram hal ini dapat menyesatkan khususnya untuk jumlah sampel yang kecil. Metode yang lebih handal adalah dengan melihat normal probability plot yang membandingkan distribusi kumulatif dari distribusi normal. Distribusi normal akan membentuk suatu garis lurus diagonal dan ploting data residual akan dibandingkan dengan garis diagonal (Ghozali, 2009:147).

Uji normalitas secara grafik dapat menyesatkan kalau tidak hati-hati secara visual kelihatan normal, padahal secara statistik bisa sebaliknya. Oleh sebab itu dianjurkan disamping uji grafik dilengkapi dengan uji statistik (Ghozali, 2009:149). Uji normalitas secara statistik dengan menggunakan uji Kolmogorov Smirnov, dengan ketentuan jika nilai Asymp.Sig. (2tailed) > 0,05 artinya variabel berdistribusi normal (Situmorang dan Muslich, 2012:100).

\section{b. Uji Multikoliniearitas}

Pengujian multikolonieritas dilakukan untuk menguji apakah pada model regresi ditemukan adanya korelasi antar variabel independen. Untuk mendeteksi adanya problem multikol, maka dapat dilakukan dengan melihat nilai Tolerance dan Variance Inflation Factor (VIF) serta besaran korelasi antar variabel independen. Nilai umum yang biasa dipakai adalah nilai Tolerance $>0,1$ atau nilai VIF $<5$, maka tidak terjadi multikolinearitas (Situmorang dan Muslich, 2012:133). 


\section{c. Uji Heteroskedastisitas}

Uji heteroskedastisitas bertujuan untuk menguji apakah dalam model regresi terjadi ketidaksamaan variance dari residual satu pengamatan yang lain. Heteroskedastisitas menunjukan bahwa variasi variabel tidak sama untuk semua pengamatan. Pada heterokedastisitas kesalahan yang terjadi tidak secara acak tetapi menunjukan hubungan yang sistematis sesuai dengan besarnya satu atau lebih variabel.

Uji heteroskedastisitas dilakukan dengan cara melihat grafik scatterplot. Apabila titiktitik menyebar secara acak, serta tersebar baik di atas maupun dibawah angka nol pada sumbu Y, maka dapat disimpulkan tidak terjadi heteroskedastisitas pada model regresi. (Ghozali 2009:107). Cara lain adalah dengan melakukan uji Glejser, dimana ketentuannya adalah jika nilai Sig > 0,05 maka tidak terjadi heteroskedastisitas pada model regresi.

\section{Analisis Regresi Linier Berganda}

Metode analisis regresi linier berganda digunakan untuk mengetahui berapa besar pengaruh variabel independen (brand image, harga, dan promosi) terhadap variabel dependen (keputusan pembelian). Data diolah secara statistik untuk keperluan analisis dan pengujian hipotesis dengan menggunakan alat bantu program SPSS 20.0 for windows.

Adapun bentuk umum persamaan regresi yang digunakan adalah sebagai berikut:

$$
\mathbf{Y}=\mathbf{a}+\mathbf{b}_{1} \mathbf{X}_{1}+\mathbf{b}_{2} \mathbf{X}_{2}+\mathbf{b}_{3} \mathbf{X}_{3}+e
$$

Keterangan :

$$
\begin{array}{ll}
\mathrm{Y} & =\text { Keputusan pembelian } \\
\mathrm{a} & =\text { Konstanta } \\
\mathrm{b}_{1}, \mathrm{~b}_{2}, \mathrm{~b}_{3} & =\text { Koefisien regresi } \\
\mathrm{X}_{1} & =\text { Brand Image } \\
\mathrm{X}_{2} & =\text { Harga } \\
\mathrm{X}_{3} & =\text { Promosi } \\
e & =\text { Standar error }
\end{array}
$$

\section{Pengujian Hipotesis}

Suatu perhitungan statistik disebut signifikan secara statistik apabila nilai uji statistik berada dalam daerah kritis (daerah dimana Ho ditolak). Sebaliknya, disebut tidak signifikan bila nilai uji statistik berada dalam daerah dimana Ho diterima.

\section{a. Uji Signifikansi Parsial (Uji t)}

Uji t menentukan seberapa besar pengaruh variabel independen (X) secara parsial terhadap variabel dependen $(\mathrm{Y})$. Kriteria pengujian adalah :

- $\mathrm{H}_{0}: \mathrm{b}_{1}=\mathrm{b}_{2}=\mathrm{b}_{3}=0$, artinya secara parsial tidak terdapat pengaruh yang positif dan signifikan antara variabel independen $\left(\mathrm{X}_{1}, \mathrm{X}_{2}\right.$, dan $\left.\mathrm{X}_{3}\right)$ yaitu brand image, harga, dan promosi terhadap variabel dependen (Y) yaitu keputusan pembelian.

- Ha : $b_{1} \neq b_{2} \neq b_{3} \neq 0$, artinya secara parsial terdapat pengaruh yang positif dan signifikan antara variabel independen $\left(\mathrm{X}_{1}, \mathrm{X}_{2}\right.$, dan $\left.\mathrm{X}_{3}\right)$ yaitu brand image, harga, dan promosi terhadap variabel dependen $(\mathrm{Y})$ yaitu keputusan pembelian.

Kriteria pengambilan keputusan :

- $\mathrm{H}_{0}$ diterima jika thitung $\leq \mathrm{t}_{\text {tabel }}$ pada $\alpha=5 \%$.

- Ha ditolak jika thitung $\geq t_{\text {tabel }}$ pada $\alpha=5 \%$.

b. Uji Signifikansi Simultan (Uji-F)

Uji-F pada dasarnya menunjukkan apakah semua variabel independen yang dimasukkan dalam model mempunyai pengaruh secara bersama-sama terhadap variabel dependen. Kriteria pengujian adalah : 
- $\mathrm{H}_{0}: \mathrm{b}_{1}=\mathrm{b}_{2}=\mathrm{b}_{3}=0$, artinya secara bersama-sama tidak terdapat pengaruh yang positif dan signifikan antara variabel independen $\left(\mathrm{X}_{1}, \mathrm{X}_{2}\right.$, dan $\left.\mathrm{X}_{3}\right)$ yaitu brand image, harga, dan promosi terhadap variabel dependen (Y) yaitu keputusan pembelian.

- Ha: $b_{1} \neq b_{2} \neq b_{3} \neq 0$, artinya secara bersama-sama terdapat pengaruh yang positif dan signifikan antara variabel independen $\left(\mathrm{X}_{1}, \mathrm{X}_{2}\right.$, dan $\left.\mathrm{X}_{3}\right)$ yaitu brand image, harga, dan promosi terhadap variabel dependen (Y) yaitu keputusan pembelian.

Kriteria pengambilan keputusan :

- $\mathrm{H}_{0}$ diterima jika $\mathrm{F}_{\text {hitung }} \leq \mathrm{F}_{\text {tabel }}$ pada $\alpha=5 \%$.

- Ha ditolak jika $F_{\text {hitung }} \geq F_{\text {tabel }}$ pada $\alpha=5 \%$.

c. Koefisien Determinasi $\left(R^{2}\right)$

Koefisien determinasi $\left(R^{2}\right)$ pada intinya mengukur seberapa besar kemampuan model dalam menerangkan variabel dependen. Jika $R^{2}$ semakin besar (mendekati satu), maka dapat dikatakan bahwa hubungan variabel independen $\left(\mathrm{X}_{1}, \mathrm{X}_{2}\right.$, dan $\left.\mathrm{X}_{3}\right)$ adalah besar terhadap variabel dependen (Y). Hal ini berarti model yang digunakan semakin kuat untuk menerangkan hubungan variabel independen yang diteliti terhadap variabel dependen. Sebaliknya, jika $R^{2}$ semakin kecil (mendekati nol) maka dapat dikatakan bahwa hubungan variabel independen $\left(\mathrm{X}_{1}, \mathrm{X}_{2}\right.$, dan $\left.\mathrm{X}_{3}\right)$ terhadap variabel dependen $(\mathrm{Y})$ semakin kecil. Hal ini berarti model yang digunakan tidak kuat. Secara umum dapat dikatakan besarnya koefisien determinasi berganda $\left(R^{2}\right)$ berada diantara 0 dan 1 atau $0 \leq R^{2} \leq 1$.

\section{HASIL DAN PEMBAHASAN}

\section{A. Hasil Uji Asumsi Klasik}

\section{a. Uji Normalitas}

Uji normalitas bertujuan untuk menguji apakah dalam model regresi, variabel pengganggu atau residual memiliki distribusi normal. Ada dua cara untuk mendeteksi apakah residual berdistribusi normal atau tidak yaitu dengan analisis grafik dan uji statistik.

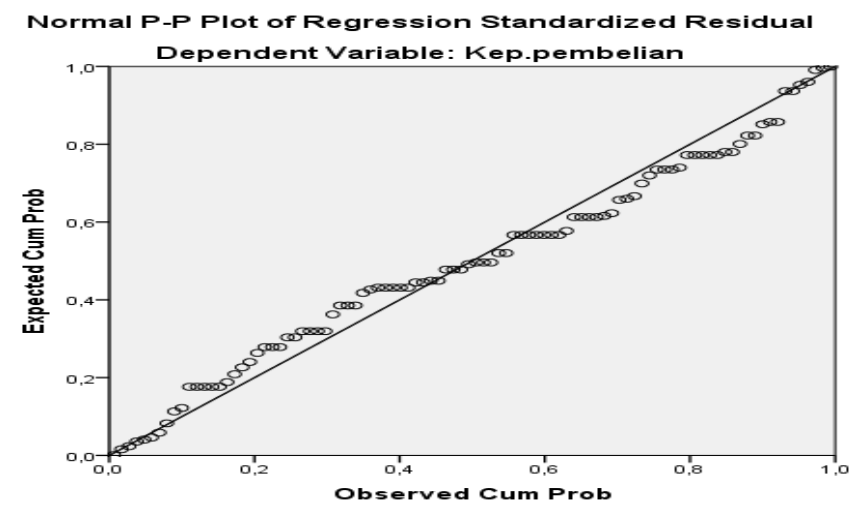

Gambar 2 Grafik P-Plot Uji Normalitas

Pada gambar dapat dilihat bahwa data (titik-titik) menyebar di sekitar garis diagonal dan mengikuti garis diagonal. Oleh karena itu, berdasarkan gambar (Normal P-P Plot Of Regression Standardized Residual) dan gambar maka dapat diambil kesimpulan bahwa data telah memenuhi uji normalitas.

Untuk memastikan apakah data disepanjang garis diagonal berdistribusi normal maka dilakukan uji Kolmogorv Smirnov (1 Sample KS) dengan melihat data residual apakah berdistribusi normal (Situmorang, et al 59:2008). Jika nilai Asymp. Sig. (2-tailed) > 0,05 maka tidak mengalami gangguan distribusi normal, jika nilai Asymp.Sig (2-tailed) $<0,05$ maka mengalami gangguan distribusi normal.

\section{Tabel 1}


Hasil Uji Kolmogorov-Smirnov One-Sample Kolmogorov-Smirnov Test

\begin{tabular}{|ll|r|}
\hline & & $\begin{array}{r}\text { Unstandardized } \\
\text { Residual }\end{array}$ \\
\hline N & Mean & 96 \\
Normal Parameters & $0 \mathrm{E}-7$ \\
& Std. Deviation &, 72379744 \\
& Absolute &, 081 \\
Most Extreme Differences & Positive &, 081 \\
& Negative &,- 073 \\
Kolmogorov-Smirnov Z & &, 793 \\
Asymp. Sig. (2-tailed) &, 556 \\
\hline a. Test distribution is Normal. & \\
b. Calculated from data. & \\
Sumber : Hasil Pengolahan SPSS, 2014 &
\end{tabular}

Pada tabel terlihat bahwa nilai Asymp.Sig. (2-tailed) adalah 0,556. Dengan demikian nilai Asymp.Sig. (2-tailed) 0,556>0,05 sehingga variabel residual berdistribusi normal.

\section{b. Uji Multikolinearitas}

Uji Multikolinearitas bertujuan untuk menguji adanya korelasi antara variabel independen. Jika terjadi korelasi maka dinamakan multikol, yaitu adanya masalah multikolinearitas. Model regresi yang baik seharusnya tidak terjadi korelasi antara variabel independen. Hasil pengolahan dapat dilihat pada tabel sebagai berikut :

Tabel 2

\section{Hasil Uji Multikolinearitas}

\begin{tabular}{|c|c|c|c|}
\hline \multirow{2}{*}{\multicolumn{2}{|c|}{ Model }} & \multicolumn{2}{|c|}{ Collinearity Statistics } \\
\hline & & Tolerance & VIF \\
\hline \multirow{4}{*}{1} & (Constant) & & \\
\hline & Brand image & ,796 & 1,257 \\
\hline & Harga & ,754 & 1,326 \\
\hline & Promosi & ,884 & 1,131 \\
\hline
\end{tabular}

Sumber : Hasil Pengolahan SPSS, 2014

Pedoman suatu model regresi yang bebas multikolinearitas adalah dengan melihat variance inflation factor (VIF) dan tolerance. Jika VIF $<5$, dan nilai tolerance harus mendekati $>0,1$ maka tidak terdapat masalah multikolinearitas. Pada tabel 4.10 dapat dilihat bahwa nilai VIF $<5$ dan nilai Tolerance $>0,1$ dengan demikian tidak ditemukan masalah multikolinearitas pada model regresi hasil penelitian.

\section{c. Uji Heteroskedostisitas}

Ada dua pendekatan untuk mendeteksi ada atau tidaknya heteroskedastisitas, yaitu :

1) Pendekatan Grafik (Grafik Scatterplot)

Dasar analisis adalah jika tidak ada pola yang jelas, serta titik-titik menyebar baik di atas dan di bawah angka 0 pada sumbu Y, maka tidak terjadi heteroskedastisitas.






\section{Gambar 3 Scatterplot}

Berdasarkan Gambar 3 dapat terlihat bahwa tidak ada pola yang jelas, serta titik-titik menyebar baik di atas dan di bawah angka 0 pada sumbu Y, maka berdasarkan metode grafik tidak terjadi heteroskedastistas pada model regresi.

2) Uji Glejser

Uji Glejser mengusulkan untuk me-regres nilai absolut residual terhadap variabel independen. Jika variabel independen signifikan secara statistik mempengaruhi variabel independen, maka ada indikasi terjadi heteroskedastisitas.

Tabel 3

Hasil Uji Glejser

Coefficients $^{\mathrm{a}}$

\begin{tabular}{|c|c|c|c|c|c|c|}
\hline \multirow{2}{*}{\multicolumn{2}{|c|}{ Model }} & \multicolumn{2}{|c|}{ Unstandardized Coefficients } & Standardized & \multirow[t]{2}{*}{$\mathrm{t}$} & \multirow[t]{2}{*}{ Sig. } \\
\hline & & $B$ & Std. Error & Beta & & \\
\hline \multirow{4}{*}{1} & (Constant) & ,607 & ,837 & & ,726 & , 470 \\
\hline & Brand image & ,091 & ,043 & ,239 & 2,120 & ,077 \\
\hline & Harga &,- 016 & ,047 &,- 040 &,- 346 & ,730 \\
\hline & Promosi &,- 094 & ,051 &,- 198 & $-1,858$ &, 066 \\
\hline
\end{tabular}

a. Dependent Variable: AbsRes

Sumber : Hasil Pengolahan SPSS, 2014,

Jika variabel independen signifikan secara statistik mempengaruhi variabel absolute residual, maka ada indikasi terjadi heteroskedastisitas. Dari Tabel 4.11 di atas dapat dilihat bahwa signifikansi variabel independen lebih besar dari 0,05 maka tidak mengalami gangguan heteroskedastisitas.

\section{Analisis Regresi Linear Berganda}

Analisis regresi linear berganda digunakan untuk mengetahui berapa besar pengaruh variabel bebas $\left(\mathrm{X}_{1}, \mathrm{X}_{2}, \mathrm{X}_{3}\right)$ terhadap variabel terikat $(\mathrm{Y})$. Maka untuk memperoleh hasil yang lebih akurat digunakan program software SPSS 20.0 for windows, maka dari Tabel coefficient dihasilkan output sebagai berikut :

\section{Tabel 4}

\section{Hasil Regresi Linear Berganda} Coefficients $^{a}$

\begin{tabular}{|c|c|c|c|c|c|c|}
\hline \multirow{2}{*}{\multicolumn{2}{|c|}{ Model }} & \multicolumn{2}{|c|}{ Unstandardized Coefficients } & Standardized & \multirow[t]{2}{*}{$\mathrm{t}$} & \multirow[t]{2}{*}{ Sig. } \\
\hline & & $B$ & Std. Error & Beta & & \\
\hline \multirow{4}{*}{1} & (Constant) & 0,625 & 0,262 & & 0,287 & 201 \\
\hline & Brand image & ,556 & ,065 &, 585 & 8,607 & ,000 \\
\hline & Harga & ,338 & 071 & ,330 & 4,731 & ,000 \\
\hline & Promosi & ,087 & 076 & 073 & 1,134 & ,260 \\
\hline
\end{tabular}

a. Dependent Variable: Kep.pembelian

Sumber : Hasil Pengolahan SPSS, 2014

Berdasarkan hasil pengolahan data seperti terlihat pada Tabel 4.12 Kolom Unstandardized Coefficients bagian B nilai koefien regresi masing-masing variabel, yaitu :

1) Konstanta (a) $=0,625$. Ini berarti bahwa apabila variabel brand image, harga, dan promosi dianggap tidak ada, maka keputusan pembelian sebesar 0,625.

2) Koefisien $X_{1}\left(b_{1}\right)=0,556$. Ini berarti bahwa jika variabel brand image meningkat satu satuan dan variabel lainnya konstan, maka keputusan pembelian meningkat sebesar 0,556 . 
3) Koefisien $X_{2}\left(b_{2}\right)=0,338$. Ini berarti bahwa jika variabel harga meningkat satu satuan dan variabel lainnya konstan, maka keputusan pembelian meningkat sebesar 0,338.

4) Koefisien $X_{3}\left(b_{3}\right)=0,087$. Ini berarti bahwa jika variabel promosi meningkat satu satuan dan variabel lainnya konstan, maka keputusan pembelian meningkat sebesar 0,087.

Berdasarkan hasil tersebut, maka persamaan regresi adalah :

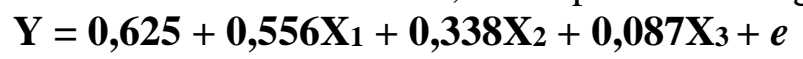

\section{Pengujian Hipotesis}

Hipotesis pada penelitian ini diuji dengan menggunakan uji signifikansi parsial (Uji t), uji signifikansi simultan (Uji F), dan koefisien determinasi $\left(R^{2}\right)$.

\section{a) Uji Signifikansi Parsial (Uji t)}

Uji $\mathrm{t}$ ini menunjukkan seberapa besar pengaruh variabel bebas (X) secara parsial/individu terhadap variabel terikat (Y). Uji t dilakukan dengan cara membandingkan nilai $t_{\text {hitung }}$ dengan $t_{\text {tabel }}$ dengan kriteria pengambilan keputusan adalah :

- $\mathrm{H}_{0}$ diterima jika $\mathrm{t}_{\text {hitung }}<\mathrm{t}_{\text {tabel }}$ pada $\alpha=5 \%$.

- Ha diterima jika $t_{\text {hitung }}>t_{\text {tabel }}$ pada $\alpha=5 \%$.


dibandingkan dengan nilai tabel pada tingkat $\alpha=5 \%$. Nilai tabel yang digunakan adalah nilai distribusi t dengan derajat bebas (df) yaitu $(\mathrm{df} 1)=\mathrm{k}-1=4-1=3$, dan (df2) $=\mathrm{n}-\mathrm{k}=96-4=92$. Uji thitung yang dilakukan adalah uji dua arah maka $t_{\text {tabel }}$ yang digunakan adalah $\mathrm{t} 5 \%$ atau $\mathrm{t}_{0,05}$ $(92)=1,66159$.

\section{Tabel 5}

\section{Hasil Uji Parsial (Uji t)}

Coefficients $^{\mathrm{a}}$

\begin{tabular}{|c|c|c|c|c|c|c|}
\hline \multirow{2}{*}{\multicolumn{2}{|c|}{ Model }} & \multicolumn{2}{|c|}{ Unstandardized Coefficients } & \multirow{2}{*}{$\begin{array}{c}\text { Standardized } \\
\text { Coefficients } \\
\text { Beta }\end{array}$} & \multirow[t]{2}{*}{$\mathrm{t}$} & \multirow[t]{2}{*}{ Sig. } \\
\hline & & $B$ & Std. Error & & & \\
\hline \multirow{4}{*}{1} & (Constant) & 0,625 & 0,262 & & 1,287 & 201 \\
\hline & Brand image & ,556 & ,065 &, 585 & 8,607 &, 000 \\
\hline & Harga & ,338 & ,071 & ,330 & 4,731 & ,000 \\
\hline & Promosi & ,087 & ,076 & 073 & 1,134 & ,260 \\
\hline
\end{tabular}

a. Dependent Variable: Kep.pembelian

Sumber : Hasil Pengolahan SPSS, 2014

Berdasarkan Tabel diatas, maka dapat dijelaskan sebagai berikut :

1) Untuk variabel Brand Image $\left(\mathrm{X}_{1}\right)$ diperoleh nilai thitung $(8,607)>t_{\text {tabel }}(1,66159)$ dengan taraf signifikansi 0,000 < 0,05. Hasil ini menunjukkan bahwa Brand Image berpengaruh positif dan signifikan terhadap keputusan pembelian. Dengan demikian hipotesis dapat diterima.

2) Untuk variabel harga $\left(X_{2}\right)$ diperoleh nilai thitung $(4,731)>t_{\text {tabel }}(1,66159)$ dengan taraf signifikansi $0,000<0,05$. Hasil ini menunjukkan bahwa harga berpengaruh positif dan signifikan terhadap keputusan pembelian. Dengan demikian hipotesis dapat diterima.

3) Untuk variabel promosi $\left(X_{3}\right)$, diperoleh nilai $t_{\text {hitung }}(1,134)<t_{\text {tabel }}(1,66159)$ dengan taraf signifikansi 0,260 >0,05. Hasil ini menunjukkan bahwa promosi berpengaruh positif tetapi tidak signifikan terhadap keputusan pembelian. Dengan demikian hipotesis ditolak.

\section{b) Uji Signifikansi Simultan (Uji F)}

Uji F (uji serentak) dilakukan untuk melihat secara bersama-sama pengaruh atau hubungan positif dan signifikan variabel bebas $\left(\mathrm{X}_{1}, \mathrm{X}_{2}\right.$, dan $\left.\mathrm{X}_{3}\right)$ berupa variabel brand image, harga dan promosi dan variabel terikat $(\mathrm{Y})$ berupa keputusan pembelian.

Kriteria pengambilan keputusan adalah :

- $\mathrm{H}_{0}$ diterima jika $\mathrm{F}_{\text {hitung }}<\mathrm{F}_{\text {tabel }}$ pada $\alpha=5 \%$. 
- Ha diterima jika $F_{\text {hitung }}>F_{\text {tabel }}$ pada $\alpha=5 \%$.

Nilai $F_{\text {hitung }}$ diperoleh dari pengolahan data SPSS 20.0 for Windows, kemudian akan dibandingkan dengan nilai $\mathrm{F}_{\text {tabel }}$ pada tingkat $\alpha=5 \%$. Nilai $\mathrm{F}_{\text {tabel }}$ yang digunakan adalah nilai distribusi $\mathrm{F}$ dengan derajat bebas (df), yaitu df1 $=4-1=3$, dan df $2=96-4=92$. Maka $F_{\text {tabel }}$ yang digunakan adalah nilai $\mathrm{F}(3: 92)=2,70$.

\section{Tabel 6}

Hasil Uji Simultan (Uji F)

ANOVAa

\begin{tabular}{|rl|r|r|r|r|r|}
\hline Model & & Sum of Squares & df & Mean Square & F & Sig. \\
\hline \multirow{2}{*}{1} & Regression & 97,564 & 3 & 32,521 & 60,117 &, $000^{\mathrm{b}}$ \\
& Residual & 49,769 & 92 &, 541 & & \\
& Total & 147,333 & 95 & & & \\
\hline
\end{tabular}

a. Dependent Variable: Kep.pembelian

b. Predictors: (Constant), Promosi, Brand image, Harga

Sumber : Hasil Pengolahan SPSS, 2014

Berdasarkan Tabel diatas dapat diketahui bahwa $F_{\text {hitung }}(60,117)>F_{\text {tabel }}(2,70)$ dengan taraf signifikansi $0,000<0,05$. Hasil ini menunjukkan bahwa secara bersama-sama variabel brand image, harga, dan promosi berpengaruh positif dan signifikan terhadap keputusan pembelian. Dengan demikian hipotesis dapat diterima.

c) Koefisien Determinasi $\left(\boldsymbol{R}^{2}\right)$

Pengujian koefisien determinasi $\left(R_{2}\right)$ bertujuan untuk mengetahui seberapa besar kemampuan variabel bebas menjelaskan variabel terikat. Dalam output SPSS, koefisien determinasi terletak pada tabel Model Summary dan tertulis $R$ Square. Namun untuk regresi linear berganda sebaiknya menggunakan nilai $R$ Square yang sudah disesuaikan atau tertulis Adjusted $R$ Square, karena disesuaikan dengan jumlah variabel bebas dalam penelitian. Nilai $R$ Square dikatakan baik jika di atas 0,5 karena nilai $R$ Square berkisar antara 0 sampai 1.

\section{Tabel 7}

\section{Koefisien Determinasi} Model Summary

\begin{tabular}{|l|r|r|r|r|}
\hline Model & $\mathrm{R}$ & $\mathrm{R}$ Square & \multicolumn{1}{c|}{$\begin{array}{c}\text { Adjusted R } \\
\text { Square }\end{array}$} & $\begin{array}{c}\text { Std. Error of the } \\
\text { Estimate }\end{array}$ \\
\hline 1 &, $814^{\mathrm{a}}$ &, 662 &, 651 &, 736 \\
\hline
\end{tabular}

a. Predictors: (Constant), Promosi, Brand image, Harga

Sumber : Hasil Pengolahan SPSS, 2014

Berdasarkan Tabel diatas dapat dijelaskan sebagai berikut :

1) Nilai $R=0,814$ berarti hubungan antara brand image $\left(\mathrm{X}_{1}\right)$, harga $\left(\mathrm{X}_{2}\right)$, dan promosi $\left(\mathrm{X}_{3}\right)$ terhadap keputusan pembelian (Y) sebesar $81,4 \%$. Artinya hubungan antar variabel sangat kuat.

2) Nilai Adjusted $R$ square sebesar 0,651 berarti $65,1 \%$ keputusan pembelian dapat dijelaskan oleh variabel brand image $\left(\mathrm{X}_{1}\right)$, harga $\left(\mathrm{X}_{2}\right)$, dan promosi $\left(\mathrm{X}_{3}\right)$. Sedangkan sisanya $34,9 \%$ dapat dijelaskan oleh faktor lain yang tidak diteliti oleh penelitian ini.

3) Standard Error of Estimated (standar deviasi) bernilai 0,736 yang berarti model regresi dinilai baik, karena semakin kecil standar deviasi berarti model akan semakin baik.

\section{B. Pembahasan}

\section{Pengaruh Brand Image Terhadap Keputusa Pembelian}

Berdasarkan jawaban responden yang diperoleh, diketahui bahwa warung mie rebus Pak Jambang sudah sangat dikenal oleh banyak orang, baik itu masyarakt Aek Nabara maupun dari luar. Mereka telah mengenal warung mie rabus Pak Jambang dan menilainya memiliki citra merek yang baik dan cita rasa makanan yang enak. 
Berdasarkan hasil uji-t, maka variabel brand image (citra merek) berpengaruh positif dan signifikan terhadap keputusan pembelian pada Warung Mie Rebus Pak Jambang. Hal ini terlihat dari nilai signifikan $(0,000)<0,05$ dan nilai $t_{\text {hitung }}(8,607)>t_{\text {tabel }}(1,66159)$.

Membangun citra merek memang cukup sulit, tetapi sekali terbentuk maka tidak mudah untuk mengubahnya. Keterkaitan pada suatu merek akan lebih kuat apabila dilandasi pada banyak pengalaman atau penampakan untuk mengkomunikasikannya. Berbagai asosiasi yang diingat konsumen dapat dirangkai sehingga membentuk citra tentang merek. Warung Mie Rebus Pak Jambang membangun citra mereknya dengan menjaga cita rasa makanan yang dijual. Dengan demikian akan terbentuk asosiasi dalam pemikiran konsumen bahwa mie rebus Pak Jambang benar-benar enak dan menyampaikannnya kepada orang lain, sehingga orang lain juga tertarik untuk membuktikan kenikmatan mie rebus Pak Jambang tersebut.

Hasil penelitian ini sejalan dengan penelitian yang dilakukan oleh Akbar (2012) dalam penelitiannya yang berjudul "Analisis Pengaruh Citra Merek, Harga, dan Kualitas Produk Terhadap Keputusan Pembelian Notebook Toshiba", dimana hasilnya bahwa citra merek berpengaruh positif dan signifikan terhadap keputusan pembelian Notebook Tashiba.

\section{Pengaruh Harga Terhadap Keputusan Pembelian}

Berdasarkan jawaban responden yang diperoleh, diketahui bahwa harga mie rebus Pak Jambang masih terjangkau dengan pendapatan konsumen. Kualitas produk dan cita rasa juga telah sesuai dengan harga yang dikeluarkan untuk mendapatkan mie rebus Pak Jambang tersebut.

Berdasarkan hasil uji-t, maka variabel harga berpengaruh positif dan signifikan terhadap keputusan pembelian pada Warung Mie Rebus Pak Jambang. Hal ini terlihat dari nilai signifikan $(0,000)<0,05$ dan nilai thitung $(4,731)>t_{\text {tabel }}(1,66159)$. Hal ini berarti harga berpengaruh dalam keputusan pembelian, karena ada variabel lain yang lebih signifikan dari harga yang lebih mempengaruhi keputusan pembelian. Apabila harga mie rebus Pak Jambang lebih mahal atau lebih murah dari yang lain, tetapi karena variabel lain yang lebih mempengaruhi keputusan pembelian, maka para konsumen tidak begitu memperhatikan harga dalam membeli.

Para konsumen tidak mempersoalkan lagi berapa harga yang harus mereka bayar untuk dapat menikmati kelezatan mie rebus Pak Jambang karena mereka tahu bagaimana kualitas yang dimiliki kecap yang melegenda ini. Namun, guna memenuhi kebutuhan khalayak lebih luas lagi, kini mie rebus Pak Jambang. Harga yang telah dibayar untuk mendapatkan mie rebus Pak Jambang tidak mengecewakan para konsumen dan membuat mereka puas membelinya.

Hasil penelitian ini sejalan dengan penelitian yang dilakukan oleh Tan (2012) dalam penelitiannya dalam penelitian yang berjudul Pengaruh Faktor Harga, Promosi, dan Pelayanan Terhadap Keputusan Konsumen Untuk Belanja di Alfamart Surabaya.

\section{Pengaruh Promosi Terhadap Keputusan Pembelian}

Berdasarkan jawaban responden yang diperoleh, diketahui bahwa warung mie rebus Pak Jambang kurang melakukan promosi melalui iklan dan promosi langsung. Akan tetapi promosi yang diterapkan warung mie rebus Pak Jambang lebih dominan dilakukan dengan cara membangun hubungan baik dengan pelanggan dan promosi dari mulut ke mulut. Kualitas produk dan cita rasa juga telah sesuai dengan harga yang dikeluarkan untuk mendapatkan mie rebus Pak Jambang tersebut.

Berdasarkan hasil uji-t, maka variabel promosi berpengaruh positif tetapi tidak signifikan terhadap keputusan pembelian pada Warung Mie Rebus Pak Jambang. Hal ini terlihat dari nilai signifikan $(0,260)>0,05$ dan nilai $t_{\text {hitung }}(1,134)<t_{\text {tabel }}(1,66159)$. Hal ini berarti bahwa promosi tidak terlalu mempengaruhi pelanggan dalam melakukan pembelian di 
warung mie rebus Pak Jambang, karena ada variabel lain yang lebih mempengaruhi yaitu image dan harga.

Hasil penelitian ini bertolak belakang dengan penelitian yang dilakukan oleh Tan (2012) yang menyatakan bahwa terdapat pengaruh positif dan signifikan promosi terhadap keputusan konsumen untuk belanja di Alfamart Surabaya.

\section{Pengaruh Brand Image, Harga, dan Promosi Terhadap Keputusan Pembelian}

Berdasarkan hasil uji F diketahui bahwa Brand Image, Harga, dan Promosi secara bersama-bersama berpengaruh positif dan signifikan terhadap keputusan pembelian pada Warung Mie Rebus Pak Jambang. Hal ini dapat dilihat dari nilai $F_{\text {hitung }}(60,117)>F_{\text {tabel }}(2,70)$ dan taraf signifikansi $0,000<0,05$.

Berdasarkan hasil uji determinasi diketahui bahwa keputusan pembelian dapat dijelaskan oleh variabel brand image $\left(\mathrm{X}_{1}\right)$, harga $\left(\mathrm{X}_{2}\right)$, dan promosi $\left(\mathrm{X}_{3}\right)$ sebesar $65,1 \%$. Sedangkan sisanya $34,9 \%$ dapat dijelaskan oleh faktor lain yang tidak diteliti oleh penelitian ini.

\section{DAFTAR PUSTAKA}

Akbar, Adam. 2012. "Analisis Pengaruh Citra Merek, Harga, dan Kualitas Produk Terhadap Keputusan Pembelian Notebook Toshiba”. Jurnal, Jakarta : Universitas Gunadarma. Angiopora, Marius P. 2007. Dasar-Dasar Pemasaran. Jakarta : PT. Raja Grafindo Persada. Ghozali, Imam. 2007. Aplikasi Analisis Multivariate dengan Program SPSS. Semarang : Badan Penerbit Universitas Diponegoro.

Handayani, 2010. Brand Operation. Jakarta : Erlangga.

Hapsari, T. Niken. 2010. Seluk Beluk Promosi dan Berbisnis. Yogyakarta : A Plus Books. Kotler, Philip dan Kevin Lane Keller. 2007. Manajemen Pemasaran. Jakarta : PT.Indeks.

Kotler, Philip dan Garry Amstrong. 2008. Prinsip-Prinsip Pemasaran. Edisi Kedua belas, Jilid 1. Jakarta : Erlangga.

Kotler, Philip. 2008. Manajemen Pemasaran. Jilid 1 dan 2. Jakarta : PT. Indeks. 2009. Manajemen Pemasaran 1. Edisi ketigabelas. Jakarta : Erlangga.

Kuncoro, Mudrajad. 2009. Metode Riset untuk Bisnis \& Ekonomi (Edisi 3). Jakarta : Erlangga. Laksana, Fajar. 2008. Manajemen Pemasaran ; Pendekatan Praktis. Yogyakarta : Graha Ilmu. Nurlisa. 2011. "Pengaruh Harga, Kualitas Produk, Dan Citra Merek Terhadap Keputusan Pembelian Kecap Manis Merek Bango (Studi Kasus Pada Ibu Rumah Tangga Di Komplek Villa Mutiara Johor Ii Dan Taman Johor Mas)”. Jurnal, Universitas Sumatra Utara.

Rangkuti, Fredy. 2009. Strategi Promosi yang Kreatif. Jakarta : PT. Gramedia Pustaka Utama. Riduwan dan Akdon. 2013. Rumus dan Data dalam Analisis Statistika. Bandung : Alfabeta.

Setiadi, Nugroho J. 2010. Perilaku Konsumen. Edisi Revisi. Jakarta : Kencana.

Shimp, Terence A. 2007. Periklanan dan Promosi (Aspek Tambahan Komunikasi Pemasaran). Jilid I, Edisi Terjemahan. Jakarta : Erlangga.

Situmorang, Syafrizal Helmi. 2011. Bisnis Konsep dan Kasus. Medan : USU Press.

Situmorang, Syafrizal Helmi, dan Muslich Lufti. 2012. Analisis Data Untuk Manajemen dan Bisnis. Medan : USU Press.

Stanton, William J. 2007. Prinsip Pemasaran, Jilid I. Jakarta : Erlangga.

Sugiyono. 2010. Metode Penelitian Kuantitatif, Kualitatif dan $R \&$ D. Bandung : Alfabeta.

Sunyoto, Danang. 2012. Dasar-Dasar Manajemen Pemasaran. Yogyakarta : Penerbit CAPS. 
Suryani, Tatik. 2008. Perilaku Konsumen : Implikasi Pada Strategi Pemasaran. Yogyakarta : Andi.

Swastha, Bashu dan Ibnu Sukotjo. 2010. Pengantar Bisnis. Yogyakarta : Liberty.

Tan, Erwin Rediono. 2011. "Pengaruh Faktor Harga, Promosi, dan Pelayanan Terhadap Keputusan Konsumen Untuk Belanja di Alfamart Surabaya". Jurnal Kewirausahaan Volume 5 Nomor 2, Desember 2011.

Tjiptono, Fandy. 2008. Pemasaran Jasa. Malang : Penerbit Bayu Media Publishing. . 2011. Strategi Pemasaran. Yogyakarta: Andi.

Umar, Husein. 2010. Riset Pemasaran dan Perilaku Konsumen. Jakarta : Gramedia Pustaka Utama. 